\title{
Correction to: Changes in transcranial motor evoked potentials during hemorrhage are associated with increased serum propofol concentrations
}

\author{
Jeremy A. Lieberman ${ }^{1,3} \cdot$ John Feiner $^{1} \cdot$ Mark Rollins $^{1} \cdot$ Russ Lyon $^{2} \cdot$ Paul Jasiukaitis $^{4}$
}

Published online: 8 November 2017

(C) Springer Science+Business Media B.V. 2017

\section{Correction to: J Clin Monit Comput \\ DOI 10.1007/s10877-017-0057-4}

In the original publication of the article, the corresponding author inadvertently omitted one of the co-authors in the author group. The corrected author group is given in this erratum.

The online version of the original article can be found under doi:10.1007/s10877-017-0057-4.

Jeremy A. Lieberman

lieberman@anesthesia.ucsf.edu

Paul Jasiukaitis

cochransci@sbcglobal.net

1 Department of Anesthesia \& Perioperative Care, UCSF, San Francisco, CA, USA

2 Division of Operating Rooms, UCSF, San Francisco, CA, USA

3 Division of Spine Anesthesia, Department of Anesthesia \& Perioperative Care, University of California, San Francisco, 4th Floor, Millberry Union, East Tower Room MUE-413, 500 Parnassus Avenue, Box 0648, San Francisco, CA 94143-0648, USA

4 Division of Operating Rooms, University of California, San Francisco, San Francisco, CA, USA 